Dig. Dis. 1987;5:I-IV

\title{
Contents, Vol. 5, 1987
}

No. 1 Colonic Motility in Health and Disease

Weber, J.; Ducrotte, P 1

Somatostatin and the Stomach

Ertan, A.; Arimura, A 13

Effects of Ethanol on the Gastric Mucosa

Guslandi, M 21

Ménétrier's Disease

Cooper, B.T 33

Pain of Chronic Pancreatitis: Etiology, Natural History, Therapy

Hacker, J.F.; Chobanian, S.J 41

Carcinoma of the Intrahepatic Bile Ducts

Brandt-Rauf, P.W.; Pincus, M.R 49

Diabetes and the Gastro-Intestinal Tract

O’Reilly, D.; Long, R.G 57

No. 2 Bile Acids and Cancer of the Large Bowel

Breuer, N.F.; Goebell, $\mathrm{H} \quad 65$

Glucose Intolerance and Hepatic, Biliary Tract and Pancreatic Dysfunction

Glick, M.E.; Hoefs, J.C.; Meshkinpour, H 78

Current Perspectives on Hepatocellular Carcinoma in Oriental and African Countries

Compared to Developed Western Countries

Omata, M 97

Surgical Treatment of Acute and Chronic Pancreatitis

Schroder, T 116

No. 3 Gastric Mucus and the Mucosal Barrier

Slomiany, B.L.; Sarosiek, J.; Slomiany, A 125

Reflux Gastritis Syndrome

Meshkinpour, H.; Wittles, J 146

Small Bowel Bacterial Overgrowth Syndrome

Sherman, P.; Lichtman, S 157

Diagnosis of Spontaneous Bacterial Peritonitis in Cirrhotic Patients

Attali, P.; Pelletier, G.; Ink, O.; Buffet, C; Etienne, J.P 172

Porphyria: Practical Advice for the Clinical Gastroenterologist and Hepatologist

Bonkovsky, H.L 179

IV

Contents

No. 4 The Enteric Nervous System in the Control of Motility and Secretion

Bywater, R.A.R.; Taylor, G.S.; Furukawa, K193

Assessing Nutritional Status in Man

Wilson, S.M.; Au, F.C

212 
Ischemic Colitis

Huet, P.; Jacobson, E.D 222

Clinical Applications of Nuclear Medicine in Gastroenterology

Taillefer, R.; McKusick, K.A 237

Author Index 252

Subject Index 253 